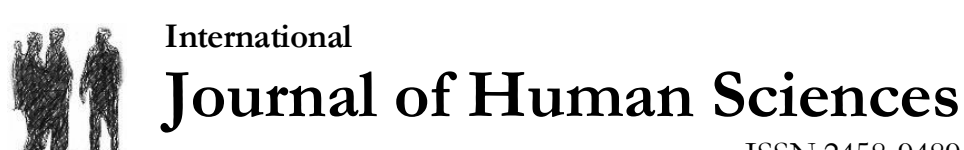 \\ ISSN:2458-9489
}

Volume 14 Issue 3 Year: 2017

\section{Education and space for mobile lives: A joint studio experiment in Ayvalık ${ }^{1}$}

\author{
Fatma Zehra Çakıci* \\ Hilal Tuğba Örmecioğlư
}

\begin{abstract}
While tragic news of hundreds of refugees, who are trying to reach to Europe through illegal and dangerous routes as they are running from violence of war, rose to rank high on the world agenda, Turkey experience the social, economic and cultural trauma of refugees expressed in millions. Education is one of the critical aspects of the problem, not only as formal education of children but life-saving support for adults who had to adapt themselves to temporary conditions and uncertain future scenarios. With these concerns in mind, the aim of this paper is to convey the process and results of 2015-2016 spring semester conjoint studio of Atatürk University with METU on "education for life-on-move". Ayvalık is chosen as the project site since it is one of the important destinations of the refugees on their way to Lesbos. Besides, the area is a historic refugee settlement, hosted many different communities, including Greek, Bosnian, Turks etc. for ages. Hence, it developed a pluralist identity and cosmopolitan culture.
\end{abstract}

Keywords: Architectural Education; Design for Refugees; Educational Space; Ayvalık; Atatürk University.

\section{Introduction}

Immigration issue is not new concept for the world. Actually, the world has experienced this problem throughout the history of civilization. Human beings could have to leave their hometown due to several reasons like war, natural hazards, and various insufficiencies and shortcomings. Especially after WW2 refugee issue seemed as a global problem and needed to take action at the international level in the 1950s. In this context, the United Nations prepared a multilateral treaty and it was ratified by 144 states around the World. The treaty, also known as the 1951 Refugee Convention, defines "a refugee as a person who is outside his or her country of nationality or habitual residence; has a well-founded fear of being persecuted because of his or her race, religion, nationality, membership of a particular social group or political opinion; and is unable or unwilling to avail bim or herself of the protection of that country, or to return there, for fear of persecution" (The Refugee Convention, 1951; Article 1 (A)(2)).

According to UNHCR figures (2016), currently there are more than 21 million people worldwide suit with this definition of refugee; which means refugee population is now more than population of many countries in the world. In the last five years, Turkey experiences huge

\footnotetext{
1 Short version of this study was orally presented at the international Congress of Architecture in Emergency held in İstanbul between $17-18^{\text {th }}$ November 2016.

2 Asst. Prof. Dr., Atatürk University, Faculty of Architecture and Design, Department of Architecture, $\underline{\text { fzehra.cakici@atauni.edu.tr }}$

${ }^{3}$ Asst. Prof. Dr., Akdeniz University, Faculty of Architecture, Department of Architecture, ormecioglu@akdeniz.edu.tr
} 
Çakıcı, F. Z., \& Örmecioğlu, H. T. (2017). Education and space for mobile lives: A joint studio experiment in Ayvalık. Journal of Human Sciences, 14(3), 2839-2847. doi:10.14687/jhs.v14i3.4666

migration flux of refugees running from the Syrian Conflict. Today about 2.5 million of refuges around the world is hosted in Turkey, which is the highest number throughout the world history. Nevertheless, we do not know how many of these people are permanent and how many of them stay as a temporary on their move to other destinations.

Refugee issue is a multifaceted problem one of which is obviously related with the refugee who already faced traumatic events and forced to leave their lands. They bring several problems for lives on move such as economic, social, cultural, ethnic and educational. Politicians, academicians and various non-governmental organizations undertake several roles and responsibilities about the problems confronting refugees.

On the other hand, the problem is related with the host country which had to deal with an unexpected problems of an unfamiliar population such as cultural clash, alienation, unemployment etc. (Çakılc1, 2017). Among these problems, inhabitation in terms of both urban and spatial design is the most visible one. Nevertheless, in addition to problem of urgent inhabitation, the host country also had to face with long term adaptation problems of the new population to existing social structure (Orhan and Gündoğar, 2015). Under these conditions the discipline of architecture take a role especially in reconciliation of socio-spatial needs of refugees and economical capabilities of host country; mostly in design of housing and educational spaces of refugees. Habitation is relatively more studied but refugee related educational designs seemed to be limited to the education of children at a young age, in fact, have to do with all ages of refugees to adapt to temporary conditions and to create opportunities for uncertain future scenarios.

As a being part of a problematic geography not only politically but also seismically Turkey had suffered of migration flux many times before due to agonizing wars-such as Balkan wars (19121913)-, population exchanges (1923) and destructions of powerful earthquakes -such as Erzincan Earthquake (1939)- left thousands of people homeless in seconds. "Whether because of an armed conflict or a natural disaster, urgent inhabitation of mass amount of people is a multifaceted problem one of which is absolutely the architecture; therefore, architecture students in Turkey had to deal with this issue more than their colleagues" (Örmecioğlu and Çakıc1, 2017).

Under these circumstances and concerns, the Departments of Architecture of Atatürk University and Middle East Technical University as $3^{\text {rd }}$ year studio partners, decided to deal with the education problem of refugees in 6th semester architectural design studio in 2015-2016 spring semester. In the architectural design studio, considering the diverse social structure and local opportunities in Ayvalık region, a training structure is designed at the high school level to help refugees participating the community life. In the scope of this paper, the final products of these studio works are presented while aiming to discuss the refugees and education issues from different perspectives.

\section{Program and Scenarios}

Atatürk University Department of Architecture $6^{\text {th }}$ semester architectural design studio placed emphasis on a high school focusing on arts and craft education both for local students and refugees to acquire a profession. 29 students divided in 11 groups were asked to prepare their own scenarios and building program based on social and cultural aspects. The groups proceed to develop different scenarios, some of which preferred fine arts education while some others focused on vocational high school concept. One group proposed culinary school, two of those followed Bauhaus school model, while others focused on hotel management and tourism vocational school education. Some groups also proposed short term courses like winter school and summer school programs for refugees staying in Ayvalik for a short time. The projects are presented in detail in the following sections. 
Çakıcı, F. Z., \& Örmecioğlu, H. T. (2017). Education and space for mobile lives: A joint studio experiment in Ayvalık. Journal of Human Sciences, 14(3), 2839-2847. doi:10.14687/jhs.v14i3.4666

\section{Site}

Ayvalık district of Balıkesir was selected as the project area, which has become an accommodation place and a passage for refugees on their move to Europe because of its proximity to the island of Lesbos. Since being home to many different communities like Turks, Greek, Bosnian and Islanders throughout history, Ayvalık has a natural 'refugee city' identity. With mobility of summer house vacationists, Ayvalık has an unstable population ranging from 40.000 to 300.000 during winter and summer times as well. Due to its cosmopolitan culture, refugees can easily find a place themselves in such a pluralist nature.

The site of the project is located at the coastline of the Aegean Sea, including five historical buildings with an olive oil factory and a reconstructed soap factory besides toasted sandwich market. Satellite image and silhouette of the site are given in Figures 1 and 2 below.

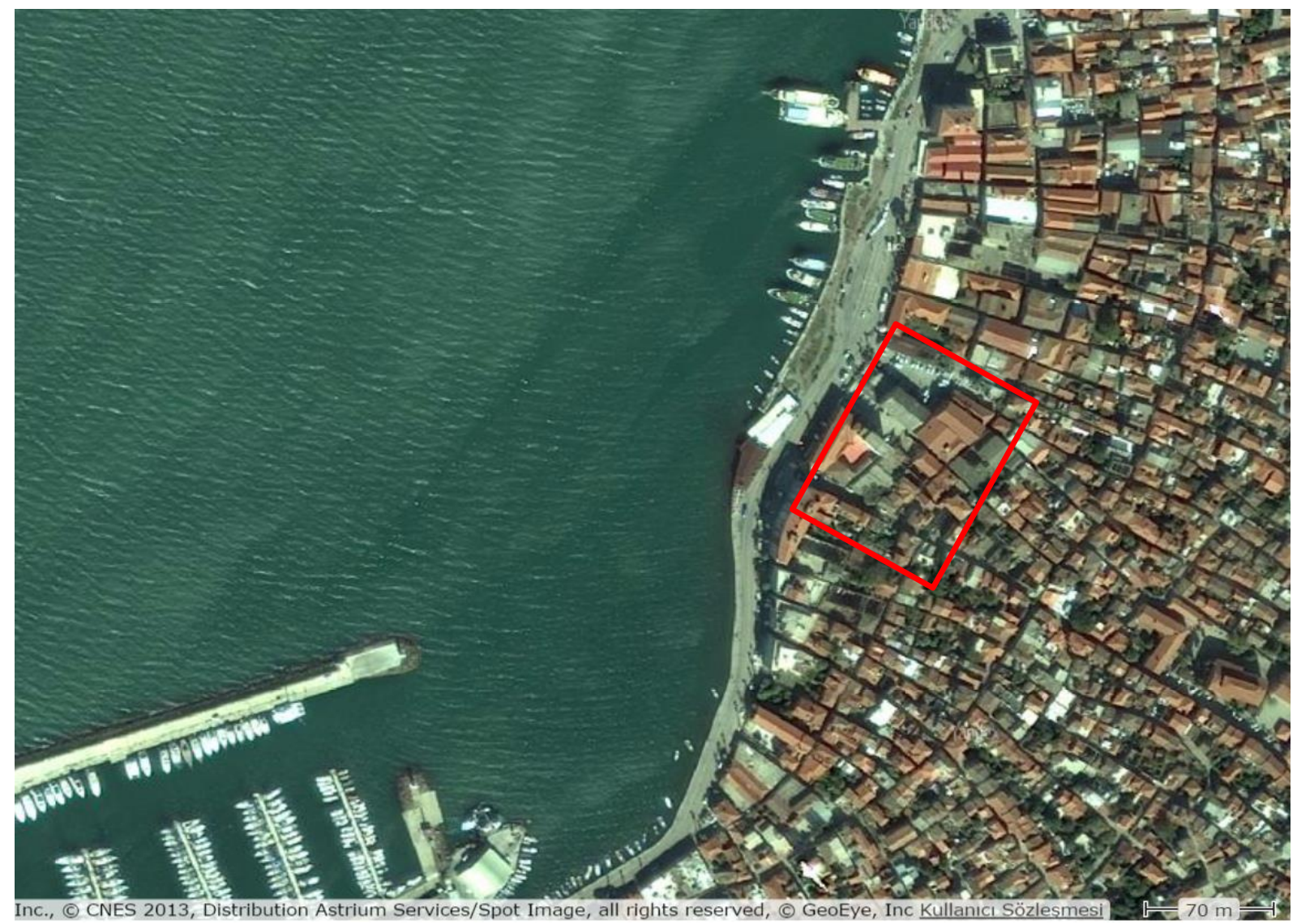

Figure 1. Satellite image of the project area (shown in red)

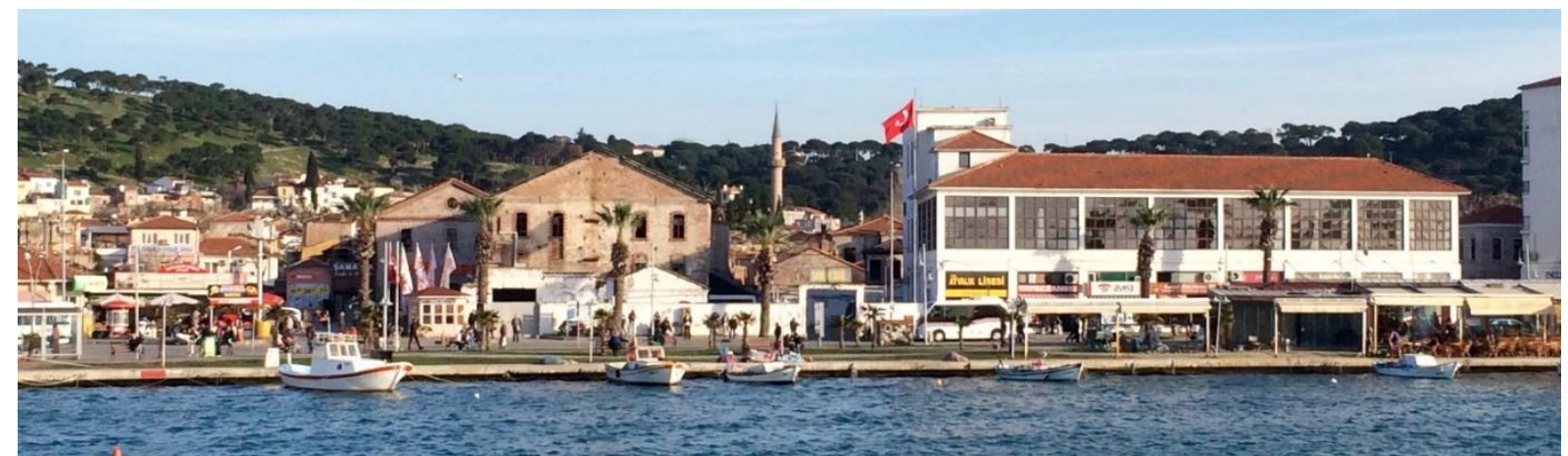

Figure 2. Silhouette of the site from Aegean Sea (from left; toasted sandwich market, olive oil factory, Ayvalık High School) taken by Aydan Balamir (2016) 
Çakıcı, F. Z., \& Örmecioğlu, H. T. (2017). Education and space for mobile lives: A joint studio experiment in Ayvalık. Journal of Human Sciences, 14(3), 2839-2847. doi:10.14687/ihs.v14i3.4666

\section{Survey Studies}

Ayvalık was visited with the students at the beginning of March 2016. $3^{\text {rd }}$ year studio handouts of Balamir-Atabaş group at METU are used as parts of the joint studio experiment between METU and Atatürk University. The students were asked to analyze the site with the near surrounding. In this context, site studies were divided in three parts, including patterns, Nolli map and whisper of the site and material. Patterns study aimed to understand the architectural fabric of the town, so as to develop a repertoire of fine 'elements' that constitute a language of 'patterns' or architectural motifs that give character to a place. The students were asked to explore traditional and modern elements, typical or atypical, from which lessons can be drawn or which can still be used in contemporary design. To this end, they were encouraged to try to capture design solutions that are worth sustaining in the effort of making new places or 'infills' in old quarters. At the second part of the site studies, the students were requested to map public and private spaces of the site and its near surrounding, representing figure-ground (or mass-space / solid-void) configurations, as in the 'Nolli Map' of Rome, drawn by Giambattista Nolli (1748). For the third part of the study, the students were asked to listen to the whisper of the site and material as described by Rafael Moneo as in text "T believe that learning to listen to the murmur of the site is one of the most necessary experiences in an architectural education" and by Louis Kahn as in the text "Even a brick wants to be something” (Balamir, 2014). While doing so, the students were encouraged to use sketches, diagrams, text and notes as well as verbal presentations.

Meanwhile, environmental analysis studies included access routes to the site, vehicular and pedestrian traffic flow, climatic conditions, orientation issues and so on. These survey studies have shown that there are collector streets parallel to the coastline while narrow linking roads are located perpendicular to the sea. It was seen that there is an intensive pedestrian traffic on Deniz Street (coast road) and along with the toasted sandwich market in the site. There are several olive oil factories along the shore, while the shapes of roofs identify the town's spatial order and tectonic character. Besides building forms, façade design, use types and number of stories of the surrounding buildings, the students took into account training needs both of refugees and local students at high school level.

\section{Studio Studies and Proposals}

Architectural design courses create an intensive learning medium to the students. An architectural design education can be described as a "learning experiment that engages in critical practice, seeking to present values instead of mere techniques, promoting investigative work rather than trying to bring exact definitions to what must be" (Ulusu Uraz and Balamir, 2006). Keeping this definition in mind, the students were encouraged to make a design research, evaluate and criticize the findings, and propose design solutions inspiring from the local parameters while respecting the codes and regulations.

At the beginning of the studio studies, the students were requested to investigate high school education focusing on arts and crafts training. They investigated and presented different high school models at the studio, starting from national high school education, fine arts high school, vocational high school and laboratory high school to hotel management and tourism vocational high school. They also searched for space organization and design principles of high schools. Since the site has historic buildings to be conserved, an infill study in a historic context was needed for architectural design project. While questioning types of training, suitable both for refugees and local students, the students were encouraged to use the local potentials of Ayvalik such as sea, sea products, olive, olive oil, soap, lead, garlic stone and so on.

Ayvalik has a great number of local patterns as rich as its heterogeneous population structure. Patterns studies showed that Ayvalik has narrow streets on which attached buildings are located around a courtyard in the middle. Buildings are mostly 2- or 3-storey with flower balconies and 'cumba' (bay windows) at the upper floors. Small rectangle windows are enhanced with either wooden shutters or wrought iron fences providing space for pot plants. Entrance doors are very 
Çakıcı, F. Z., \& Örmecioğlu, H. T. (2017). Education and space for mobile lives: A joint studio experiment in Ayvalık. Journal of Human Sciences, 14(3), 2839-2847. doi:10.14687/jhs.v14i3.4666

remarkable, representing the level of wealthy of the owner. Tall doors are decorated with posts, local motives and glass, often elevated with two or three steps. Colorful plastered façades are enriched with flowers while saddle roofs and wooden eaves are preferred at top of the buildings (Figure 3).
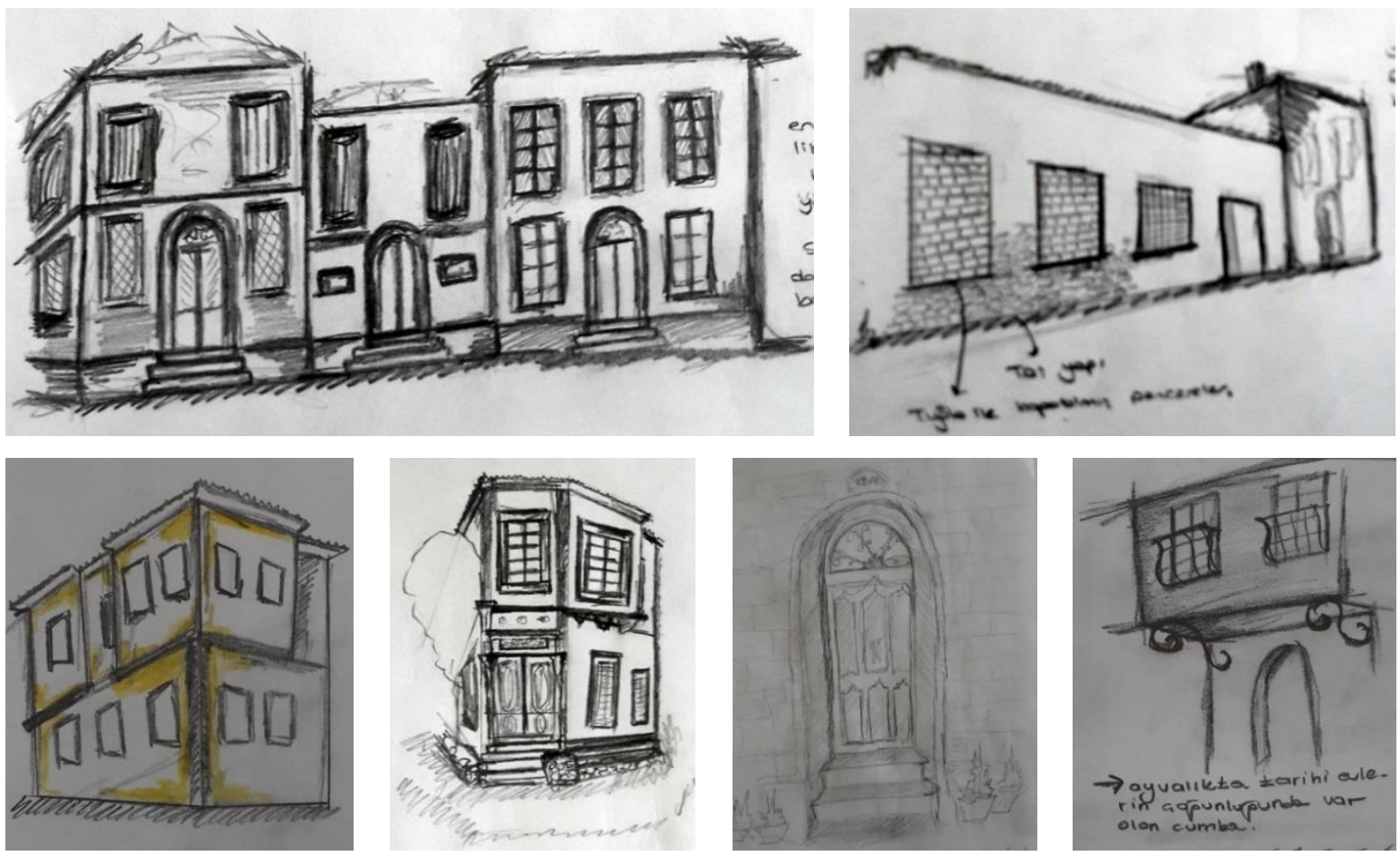

Figure 3. Sketches showing building forms, façade organization and material use in Ayvalık

Environmental analysis and Nolli map studies helped to identify public and private spaces, building types and functions, façade organization, streets and traffic flow as well as figure-ground configurations showing sizes of buildings and existing land uses. The students took photographs and made sketches of school buildings in Ayvalık as well to examine building configurations, orientation, form and component alternatives (Figure 4).
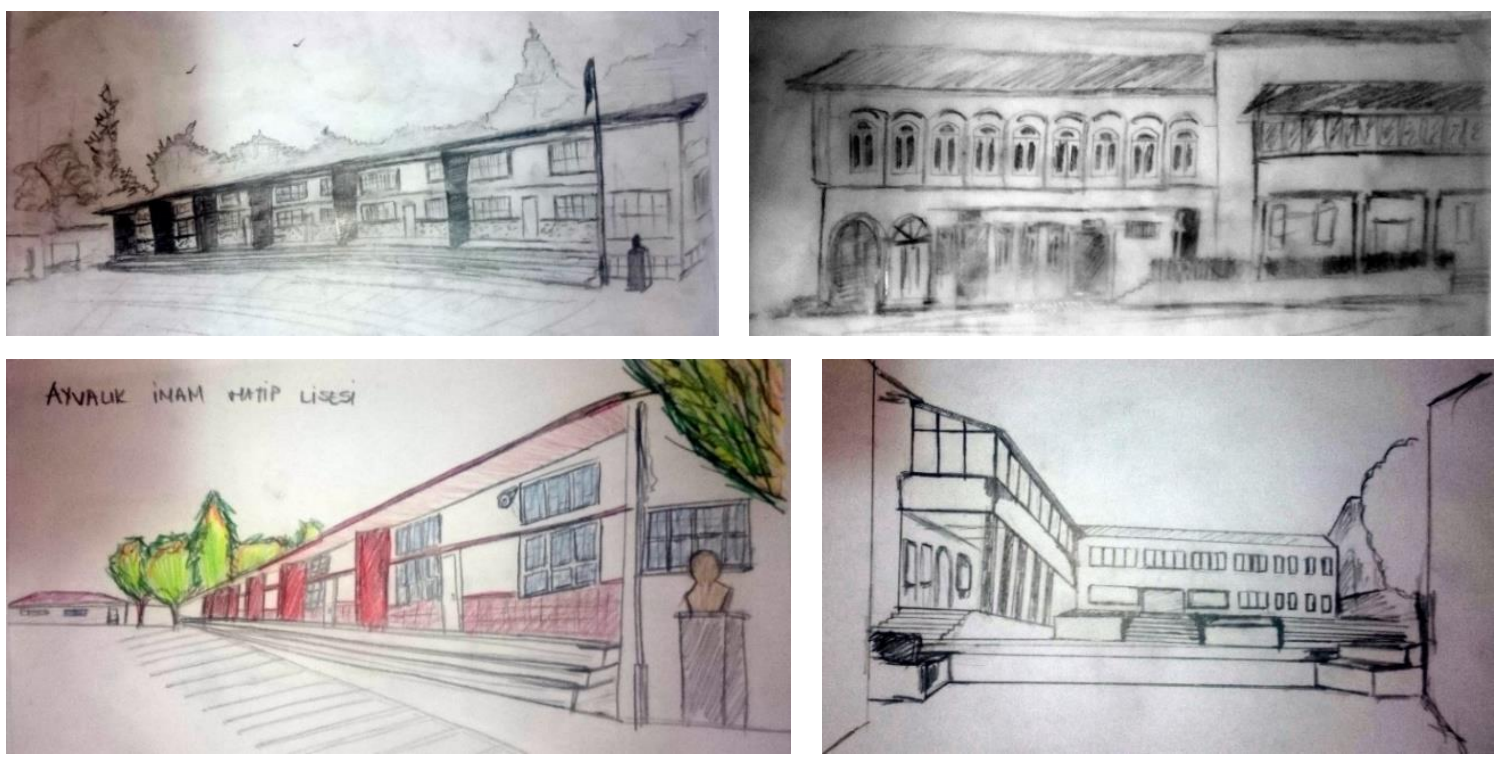

Figure 4. Sketches of school buildings in Ayvalik 
Çakıcı, F. Z., \& Örmecioğlu, H. T. (2017). Education and space for mobile lives: A joint studio experiment in Ayvalık. Journal of Human Sciences, 14(3), 2839-2847. doi:10.14687/ihs.v14i3.4666

The studio studies questioned the formation of a high school building both in $2 \mathrm{D}$ and $3 \mathrm{D}$ mediums to seek for the position/responses of a school building in an urban scale regarding the historic context. 2D medium deals with the silhouette on Deniz Street facing the West and Aegean Sea while 3D medium examined the places, sizes and forms of the buildings by means of physical and digital models. Silhouette studies were impressed by factory chimneys, building heights and roofline formations in Ayvalik while form proposals were restricted mostly by the existing historic buildings and pedestrian and vehicle traffic flow in the site.

Silhouette studies and conceptual model studies gave special importance to the response of the proposals both in urban and historic context. Students proposed lower buildings at north where toasted market and low-rise buildings are located while higher blocks were placed at south where there is a serial of mid-rise buildings (Figure 5).
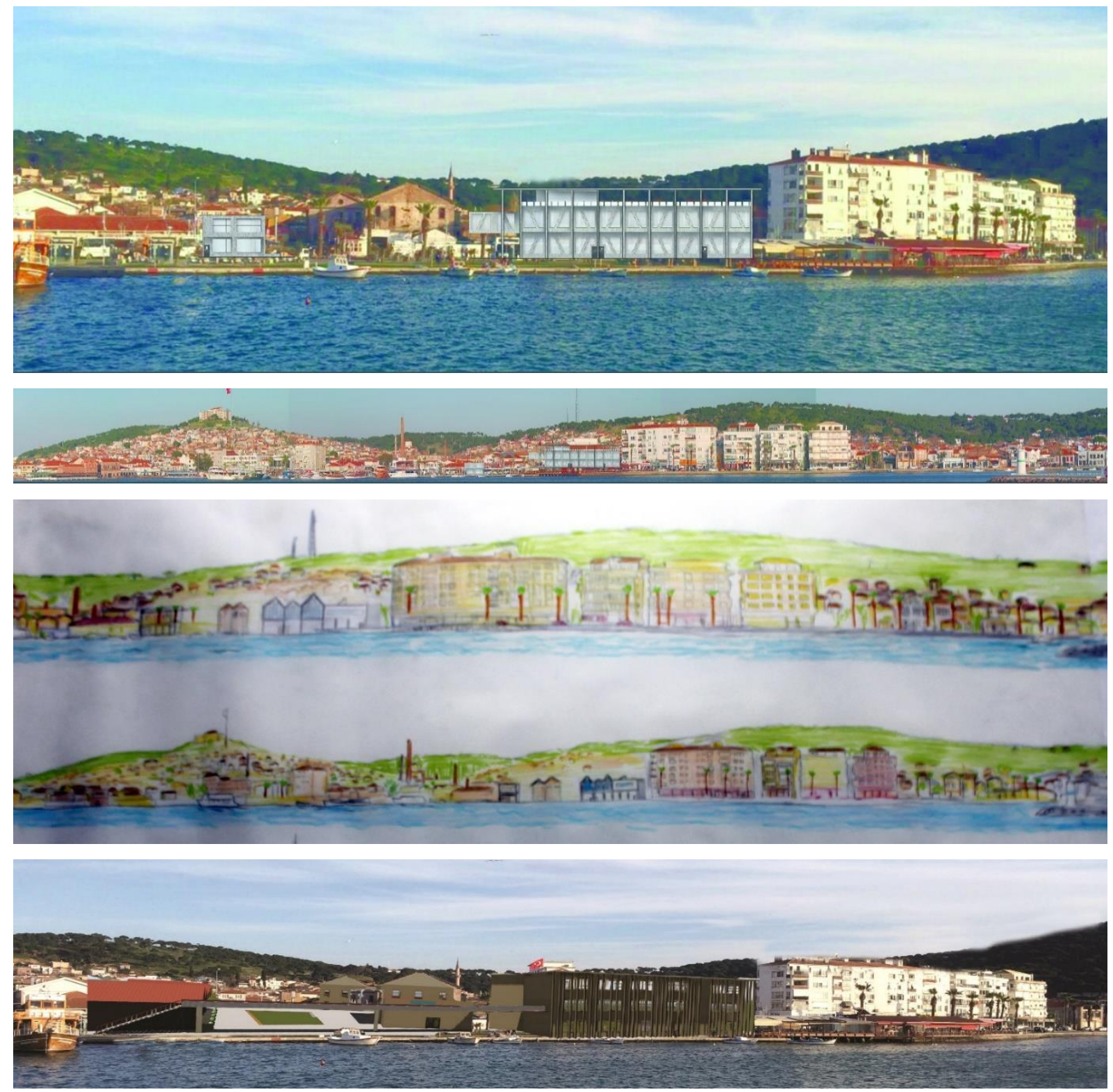

Figure 5. Silhouette studies 
Çakıcı, F. Z., \& Örmecioğlu, H. T. (2017). Education and space for mobile lives: A joint studio experiment in Ayvalık. Journal of Human Sciences, 14(3), 2839-2847. doi:10.14687/jhs.v14i3.4666

Conceptual model proposals focused on gathering school blocks in a historic context. Since the site has five historic buildings, the students were asked to preserve the façades of these buildings. On the other hand, since front elevation on Deniz Street is facing west, it was needed for classes to take precautions to sun coming from west. Therefore, orientation of classes and sun breakers were examined both in façade design and space organization (Figure 6).

One of the main questions in the design studio concerned with the relationship between the school building and its near surrounding. In this context, most groups preferred an inclusive design approach by inviting pedestrians to the school building to exhibit and sell the products. This would provide income both for local and refugee students while giving training by means of vocational courses. Under these circumstances, final products of the design studio considered design criteria and legislations for school buildings as well as building techniques, technology, use of local materials and climatic conditions at the same.

On the site plan, an infill study was handled where historic buildings were preserved as they are, new blocks and functions were proposed according to the school program. Most of the groups preferred to preserve the public square and toasted market with renovations. They also proposed to use the historic buildings to be preserved on the site, old olive oil factory building and Migros building, as cultural center of the school complex like exhibition hall and conference hall, while placing administration offices to the historic storage building. The renovated factory building and residential building series were replaced with new blocks and infills. Two groups suggested to link the school buildings and the coast with a pedestrian overpass. Each group presented their projects in $2 \mathrm{D}$ and $3 \mathrm{D}$ both in digital and physical medium with the near surrounding in order to evaluate the aptness of the design proposals with the environment. Final jury products are presented in Figures 7-9 as follows.
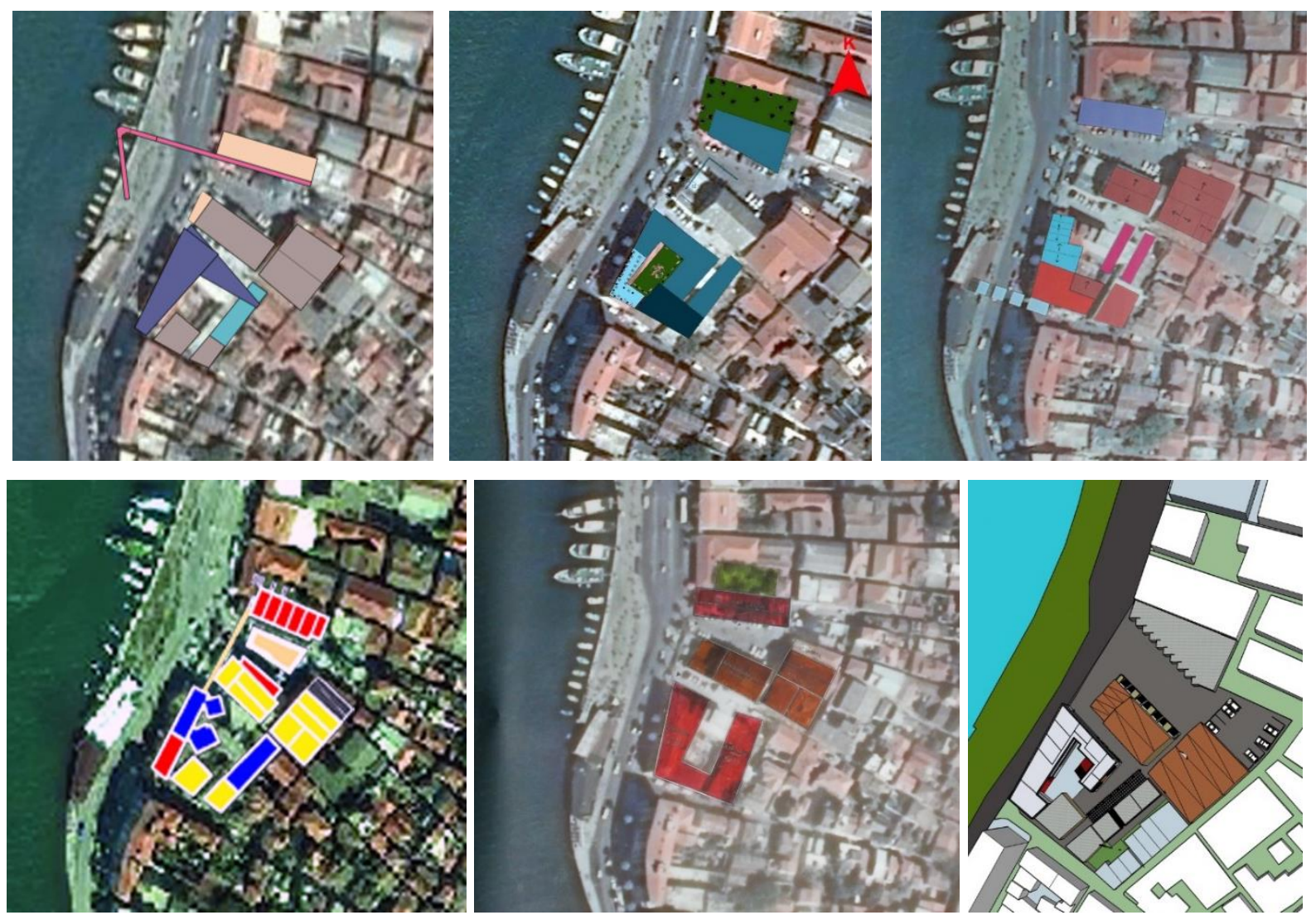

Figure 7. Site plan proposals 
Çakıcı, F. Z., \& Örmecioğlu, H. T. (2017). Education and space for mobile lives: A joint studio experiment in Ayvalık. Journal of Human Sciences, 14(3), 2839-2847. doi:10.14687/jhs.v14i3.4666
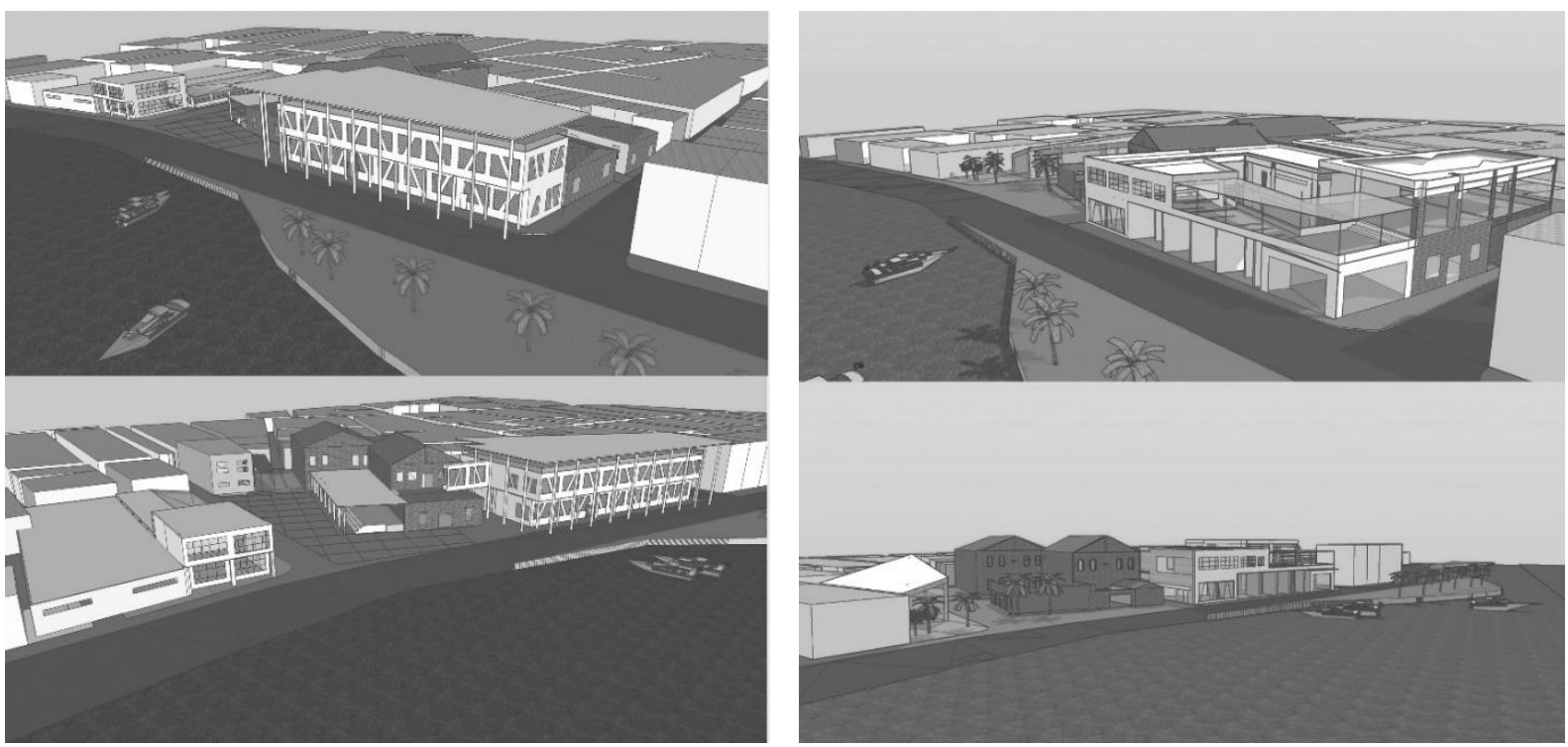

Figure 8. Final jury projects
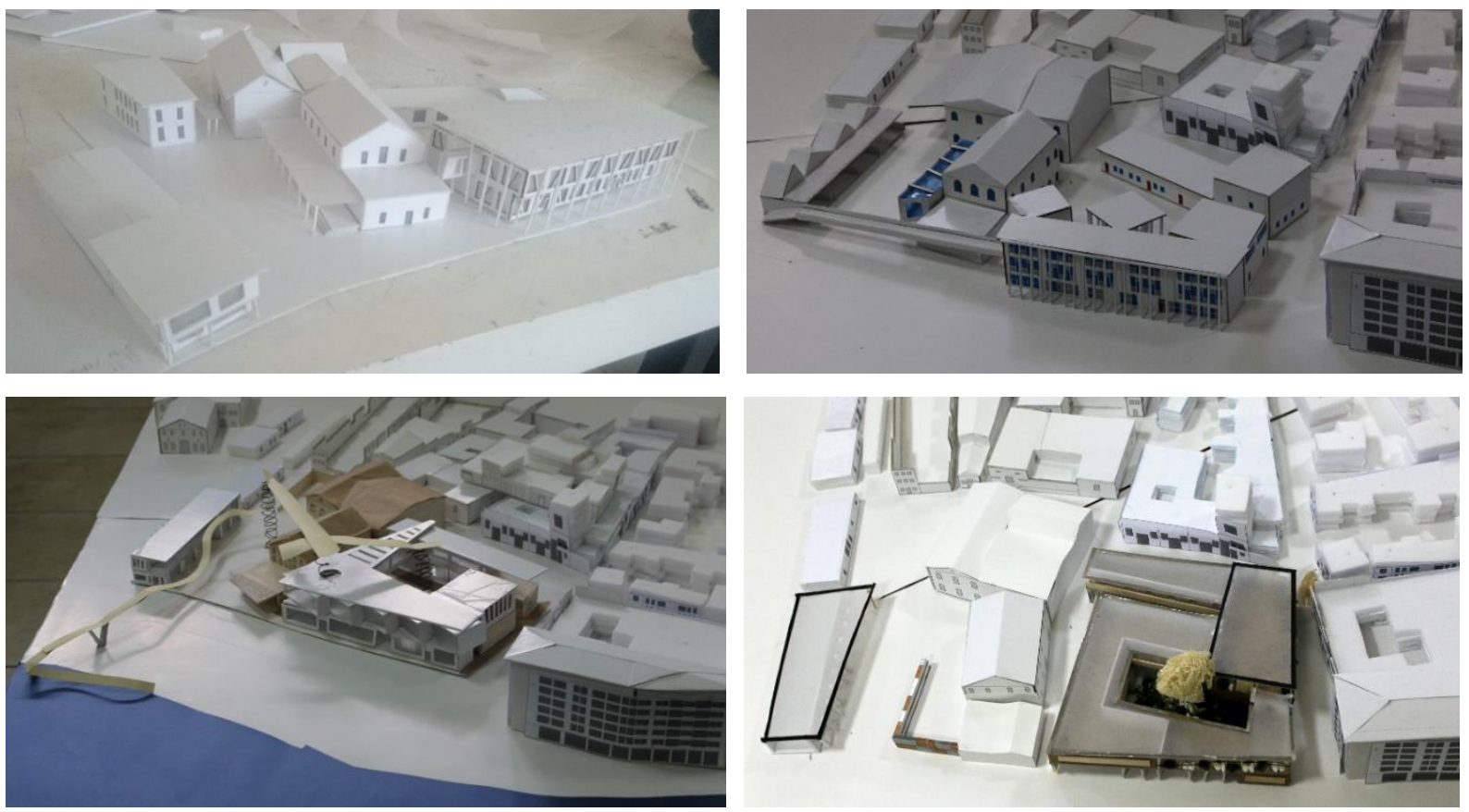

Figure 9. Final jury projects

\section{Results and Discussions}

In the studio studies of the $6^{\text {th }}$ semester architectural design studio in 2015-2016 spring semester, the students experienced a twofold design problem, questioning the formation of a high school building on a multi leveled socio-cultural geography while searching for solution of a recent but also an old problem of Anatolia, the refugee crisis.

The joint studio program encouraged the students to study harder. During the site studies in Ayvalik, the students of the two universities met and worked on the site together. Due to being a member of a joint studio experiment, the students worked in a contest medium while creating an environment to share photos, sketches, drawings, references, analysis studies and developing common acceptances. From the instructors' point of view, the joint program was carried out in two universities meanwhile enabling exchanging ideas and teaching methods. The studio instructors of 
METU visited Atatürk University monthly and joined the juries during the semester and the final jury evaluations. This process was very beneficial in terms of institutional communication between the two architecture schools.

The students tried to develop an inclusive design solution not only for the refugee problem but also for historic district of Ayvalık, which already has a cosmopolitan culture. While trying to make an infill design in a historic plot which has five existing historic buildings they had to compromise, they also searched for the traces of local culture. Besides, the area is a coastal place where the industrial and historic silhouette is an input and a characteristic which had to be delicately handled.

Last and the most important concern of the studio was education for lives on the move. Most of the students adopt an inclusive approach combining both for refugees and local students in education spaces, and achieve a social cohesion. Diverse scenarios from vocational high schools to short term seasonal courses were proposed. While questioning types of training, the students benefited from the local potentials such as olive, lead and garlic stone etc.

\section{Acknowledgments}

We would like to thank the joint studio team from both universities METU and Atatürk University, Prof. Dr. Aydan Balamir, Asst. Prof. Dr. Fatma Zehra Çakıcı, Inst. Kadri Atabaş, Res. Asst. Gülnur Güler and Res. Asst. Tuncer Çağrı Çakmur, as they generously shared their experience with us. We are especially thankful Prof. Dr. Aydan Balamir for her precious comments on the paper.

\section{References}

1951 Convention relating to the status of refugees and its 1967 Protocol, Retrieved from http://www.unhcr.org/about-us/background/4ec262df9/1951-convention-relating-statusrefugees-its-1967-protocol.html

Balamir, A., 2014, Reflective Study of Site and Precedents in Design Studio, Connecting the Disconnected, International Conference on Architectural Education, Islamabad, 19-21 December 2014.

Çakı1lc1, E., 2017, Do Syrian refugees a real impact on local unemployment in Turkey?. Journal of Human Sciences, 14(2), 1207-1214. doi:10.14687/jhs.v14i2.4393.

Orhan, O. and Gündoğar, S.S. 2015, Suriyeli Sı̆̆ınmacıların Türkiye’ye Etkileri, Ortadoğu Stratejik Araştırmalar Merkezi, ORSAM Rapor No: 195, Ocak 2015, Ankara.

Örmecioğlu, H.T. and Çakıc1, F.Z., 2017, Learning from Designing for Refugees, The Journal of International Social Research, vol. 10, issue 50, s. 559-564.

The 1951 Refugee Convention, Retrieved from http://www.unhcr.org/1951-refugeeconvention.html.

The Refugee Convention, 1951, the United Nations High Commissioner for Refugees (UNHCR), Retrieved from http://www.unhcr.org/4ca34be29.pdf.

Ulusu Uraz, T. and Balamir, A., 2006, Themes of Place and Space in Design Teaching: A Joint Studio Experiment in Amasya, METU JFA 2006/1, (23:1) 1-18.

UNHCR Figures at a Glance, Retrieved from http://www.unhcr.org/uk/figures-at-a-glance.html 